\title{
Ameliorative, Ecological and Landscape Roles of Făget Forest, Cluj-Napoca, Romania, and Possibilities of Avoiding Risks Based on GIS Landslide Susceptibility Map
}

\author{
Paul SESTRAS ${ }^{1,2,3}$, Mircea V. BONDREA², Horațiu CETEAN ${ }^{3}$, \\ Tudor SĂLĂGEAN ${ }^{3}$, Ştefan BILAŞCO ${ }^{4}$, Sanda NAȘ ${ }^{2 *}$, Velibor SPALEVIC ${ }^{5}$, \\ Spyros FOUNTAS ${ }^{6}$, Sorin M. CIMPEANU ${ }^{1}$
}

\author{
${ }^{1}$ University of Agronomic Sciences and Veterinary Medicine Bucharest, 59 Mărăşti Blvd,District 1, 011464, Bucharest, \\ Romania;paul.sestras@usamv.ro;sorin.cimpeanu@usamv.ro \\ ${ }^{2}$ Technical University of Cluj-Napoca, Faculty of Civil Engineering, Department of Terrestrial Measurement and Cadastre, 25 G. Baritiu St., \\ 400027 Cluj-Napoca, Romania; mircea_bondrea@yahoo.com; sanda.nas@mtc.utcluj.ro (corresponding author) \\ ${ }^{3}$ University of Agricultural Sciences and Veterinary Medicine, 3-5 Manastur St., 400372 Cluj-Napoca, \\ Romania; hory.cetean@yahoo.com; tudor.salagean@usamvcluj.ro \\ 4"Babes-Bolyai”University, Faculty of Geography, 400006 Cluj-Napoca, Romania; sbilasco@geografie.ubbcluj.ro \\ ${ }^{5}$ University of Montenegro, Geography Department of the Faculty of Philosophy, D. Bojovica, 81400 Niksic, \\ Montenegro; velibor.spalevic@gmail.com \\ ${ }^{6}$ Agricultural University of Athens, Department of Resource Management and Agricultural Engineering, Iera Odos 75, Athina 118 55, \\ Greece;sfountas@aua.gr
}

\begin{abstract}
The functions and conventional roles of the forests have to be largely reconsidered when such forests are located in the close proximity of urban centres. The subject of this study was to evaluate different natural risks, especially landslides at an experimental study area that is located in Făget Forest, near the city of Cluj-Napoca, North-West of Romania. Although most of this area is stabilized, human activity became in the last period the most aggressive and active factor that can induce changes in slopes stability. The evaluation based on new changes at the terrain and constructions has clearly revealed the effect of the unprecedented urban sprawl and the expansion of infrastructure elements and residential buildings. Landslide susceptibility map was elaborated using a bivariate statistical analysis and the Geographical Information System (GIS) technology on a predetermined path inside the forest, as well as obtaining valuable information about the tree species. Based on 14 surveys, each of them covering an area of $500 \mathrm{~m}^{2}$ on a longitudinal transect of the forest, there were identified relatively few tree species with a significant share: Carpinus betulus (42.9\%), Fagus sylvatica (24.9\%), Quercus petraea (23.2\%) and other species (9\%). Their positive roles in avoiding or limiting the flow on slopes, flooding, landslides are different depending on the position, terrain, forest composition, trees density, slope, exposition, but it is fundamentally beneficial. Furthermore, these species can assure productive (as wood), ameliorative, ecological, landscape, cultural, educational, relaxation roles, and consequently inestimable values.
\end{abstract}

Keywords: database, forest inventory, GIS, landslides, landscape, spatial analysis

\section{Introduction}

The biodiversity of ecosystems is under a permanent threat and a similar menace is found at national as well as at the global level due to the reduction of forest areas, excessive pollution, climate change and anthropogenic interventions with destructive effects. Increased operational work, performed poorly and aimed to financial goals only, leads to failure in ensuring continuity of ecosystem functions, affecting the quality of forest genetic resources and biodiversity (Aerts and Honnay, 2011; Davis et al., 2017).

Forests and green spaces are essential to the urban ecosystem and can mitigate temperature, decrease pollution, 
soil erosion, increase aesthetics and provide a place for recreation. Urban areas are especially vulnerable to high temperatures, which will intensify in the future due to climate change (Arnds et al., 2015; Fikfak et al., 2015). Urban vegetation and urban forest play an important role in decreasing land surface temperature (Fikfak et al., 2017). Trees can also contribute by direct and indirect ways to reduce the carbon dioxide in the atmosphere and also play a crucial role in mitigating landslides.

The forests around the city of Cluj-Napoca, especially Făget Forest, are a prime example because of the close proximity between them. This is the study area where we examine the population growth, urbanization, effects of climate change, erosion, pollution and landslides that the metropolitan area is subjected to.

At the present time, in Romania, because of poor inventory management and outdated maps and records, a Geographic Information Systems (GIS) implemented in forestry is required to solve much of these issues. It is essential to establish an accurate database for the local forest districts that will help further development, management and planning (Merem et al., 2008). Such GIS application can incorporate different spatial data as well as database that include tree location, species, diameter, height, canopy width, condition, age and growth recordings (Lwin et al., 2012). In addition to tree attribute data, such application can include other relevant features such as monitor tree health and growth, offers accurate predictions by means of extrapolation on areas where no forest inventory was made and a landslide susceptibility map. Integrating different map layers into an urban tree management project improves insight for decision making, helps cities manage forestry projects efficiently and reduce management costs (Stewart, 2010; Tasoulas et al., 2013).

Landslides along with erosion processes represent natural hazards with a large area of manifestation in Romania, including the city of Cluj-Napoca and the adjacent areas because the hilly terrain and geomorphology are very susceptible to these risks (Carrara et al., 1999; Armas, 2011). Landslides are part of the gravitational processes that occur when the steady state of the slopes is affected as a result of overgrowth of the geological substrate on clay or marl deposits due to a period of abundant precipitation or seismic movements (Magliulo et al., 2008). Besides the natural causes that trigger landslides, the anthropogenic intervention in the territory is also a main factor due to the overburdening slopes with construction and with massive deforestations (Petrea $e$ t al., 2014; Roşca $e t$ al., 2015). In order to identify the spatial susceptibility of landslides, a complex database is required that includes both triggering factors and causes of landslides such as: the lithological coefficient represented by the geology of the analysed region, the geomorphologic coefficient that takes into account the slope and altitude of the relief, the forest and anthropic coefficient depending on the land use and the trigger factors, the hydro-climatic coefficient taking into account the amount of rainfall available to the analysed region and the seismic coefficient (Poesen et al., 2003; Rickli et al., 2009).

The main purpose of this study was to obtain information for a good knowledge of the concrete situations in the selected areas, applying scientific assessment of biodiversity, setting a model for future large scale implementations.

\section{Materials and Methods}

\section{Research area}

The Făget-Chinteni Forest District is in the close vicinity of the city Cluj-Napoca, located in the NorthWestern part of Romania (Fig. 1). Cluj-Napoca, a city with great morphological and landscape diversity and a population of over 450,000 inhabitants (including the metropolitan area), faces unprecedented expansion of the city limits and population. With a general move towards urbanization, land is becoming an increasingly difficult resource to manage and preserve, and the local forests are no exception to the constant anthropic interferences (Dierwechter $e t$ al., 2008). The local authorities maintain strict laws concerning the forests, but as a result of the city growth and the rapid construction rate, land began to be occupied up to the forest edge, as well as new roads and bypasses that go through existing forests, damaging the ecosystem and the stability of the soil.

Production unit Fagget-Chinteni is located on the Someşan Plateau, the subdivision "Dealurile Clujului" (The Hills of Cluj), on both slopes of the middle course of Somesul Mic River. The forest district Făget-Chinteni production unit is managed by the National Forestry Directorate, the area of the unit is 3055 hectares.

\section{Geomorphology, geology, climate}

The production unit Făget-Chinteni is located in the North-Western part of the larger Transylvanian Plateau. The configuration of the terrain is mostly wavy, flat type or mixed configurations were recorded in only a few cases.

The lithological substrate of the territory, as the parental material on which the soils were formed, is heterogeneous and consists of muddy clays, clays, rocks, marl, limestone, siliceous sands, sands, plasters, conglomerates.

The production unit's territory is located in an area with moderate continental climate. The gradual increase of the altitude from East to West entails a vertical elevation of all climatic elements. Thus, as the altitude increases, the temperature and atmospheric pressure decrease and precipitation, humidity and wind speed increase. The hydrological regime is variable, with large spring waters, in the summer some ripples sap, and then in autumn the waters rise again.

The average temperature of the territory is $8.2{ }^{\circ} \mathrm{C}$, maintaining in the lower part (altitudes of $400 \mathrm{~m}$ ) around $9^{\circ} \mathrm{C}$, so that in the upper part (altitude of $800 \mathrm{~m}$ ) it drops to $7.5^{\circ} \mathrm{C}$. In observing periodic variations in temperature, a normal run was noted. Harmful to forest vegetation are only extreme values (maximum and minimum) and sometimes late and early frosts.

Average annual rainfall is moderate in volume, with the annual average between $600-700 \mathrm{~mm}$ respecting the same vertical elevation as temperatures. Thus rainfall increases from East to West. Snowfall is usually recorded between October and April. Torrential rains occur in the period July-August, with approx. 22-23\% of the annual rainfall. 
294

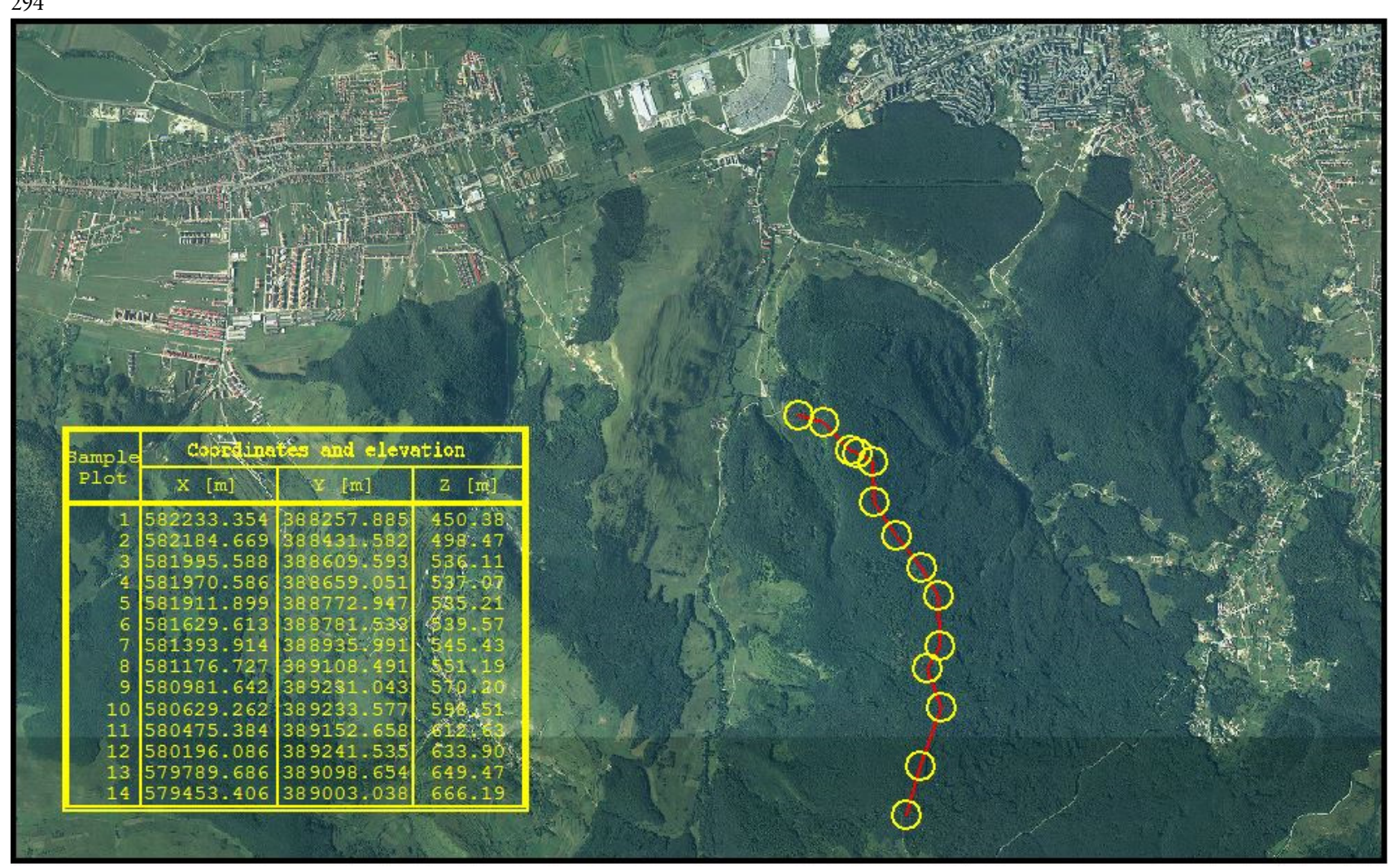

Fig. 1. South-Western part of Cluj-Napoca city, the transect of the forest and the location of the 14 surveys with coordinates and elevations

After analysing all the stationary factors (climatic, geomorphological, geological, pedological) and the forest formations existing within Forest District Făget-Chinteni, it can be said that good conditions are present for the development of beech, sessile oak, hornbeam and other species.

\section{Instruments and database}

At each of the 14 sample plots chosen along the forest transect, both forest inventory and topographic measurement were performed. The coordinates were obtained using the GNSS RTK technology and a Stonex S8 GPS. The coordinates were expressed in the Romanian National Projection System, respectively the Stereographic Projection 1970 and the elevations were reported to the Black Sea level. The accuracy of coordinates determined by RTK method of the Stonex GPS was $14 \mathrm{~mm}+1 \mathrm{ppm}$ in a horizontal direction and $20 \mathrm{~mm}+1 \mathrm{ppm}$ in vertical direction. The real-time kinematic based global positioning system (RTK-GNSS) enabled by satellite navigation offers a modern alternative technology to the previous topographic instruments (Peyret et al., 2000; Pirti et al., 2010). The topographic measurements were performed in March, when the snow has melted and the trees had no leafs yet, thus a good connection to the satellites was possible and accurate data obtained (fixed position) (Pirti et al., 2013). At the post processing stage, the cross-section profile was obtained (Fig. 2). The total length of the path thought the forest was $3295.33 \mathrm{~m}$ and the elevation of the first sample plot and the last was $450.38 \mathrm{~m}$ and $666.19 \mathrm{~m}$, thus an elevation difference of $251.81 \mathrm{~m}$.
Each of the sample plots had a central tree where the coordinates were measured, after this stage, the forest inventory began on a round area covering $500 \mathrm{~m}^{2}$ obtained by stretching a rope with a length of $12.6 \mathrm{~m}$ from the central tree (Fig. 3) in all directions, thus establishing the perimeter.

In order to carry out the study, quantitative and qualitative characteristics were taken into account, with measurements and observations being made on 411 specimens of tree species. The base diameter and the diameter at $1.30 \mathrm{~m}$ from the base - 'dbh' (diameter at breast height) were measured with a tree caliper. The height and the self-pruning were obtained using a dendrometer. Crown diameter was determined by measuring the diameter of the crown projection, in two perpendicular directions and

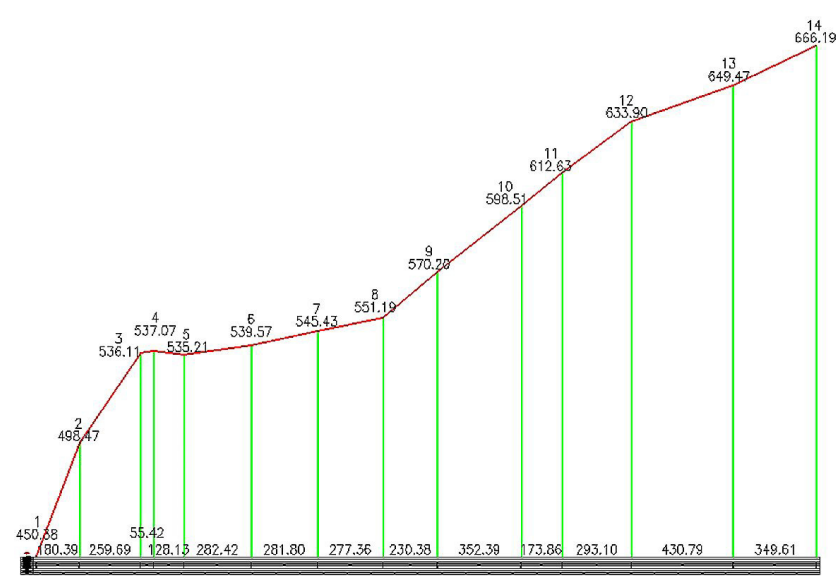

Fig. 2. Cross-section profile 


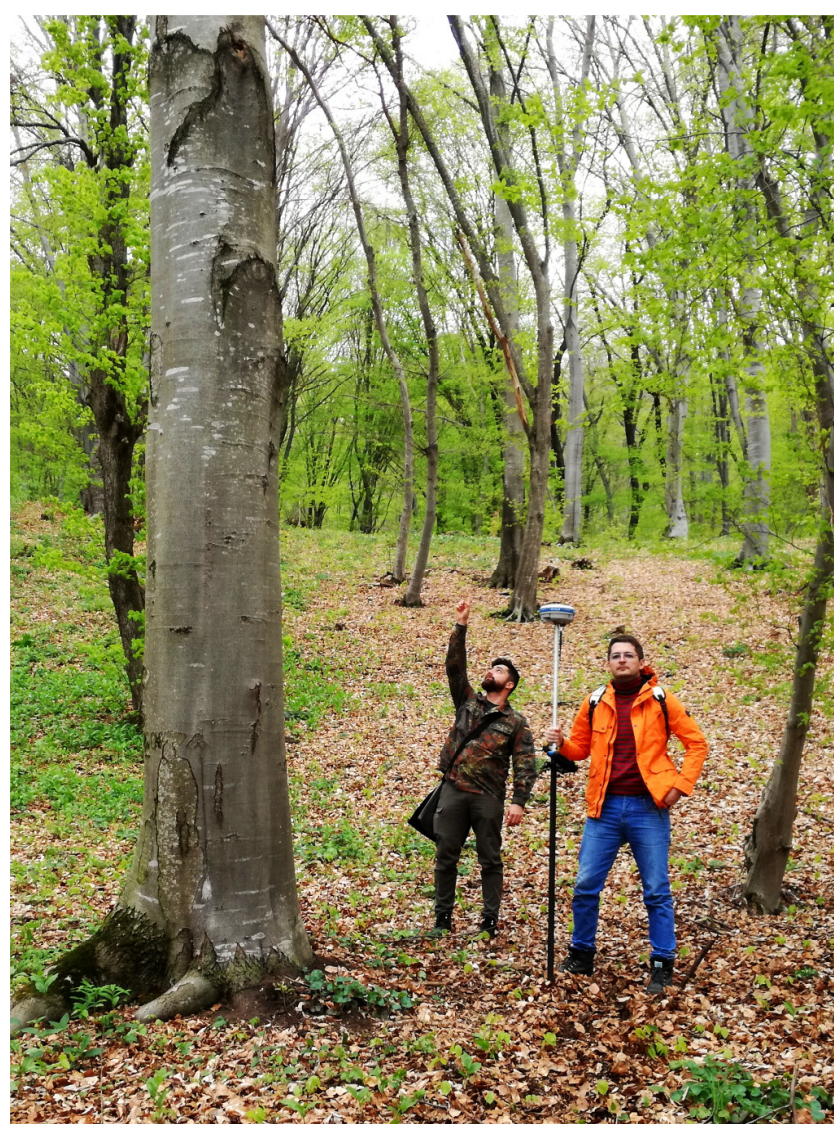

Fig. 3. Choosing the tree as the centre of the sample plot

calculating the arithmetic mean of the two measured results. The insertion angle was determined with the help of a digital protractor. For the quality class, observations were made by visual appreciation of every individual taken in calculation. The trees were separated in four quality classes, marked from I to IV according to the proportion of industry wood from the total height (Table 1).

\section{Results and Discussion}

Because of the technological progress in satellite remote sensing and the Geographical Information System (GIS) software, the advantage of increased accuracy and spatial analysis establish the GIS applications as the perfect solution for reliable resources and land administration (Hupy et al., 2008). Additionally, GIS model is capable of supporting an integrative database and management and increase of economically efficiency of the local forests. It is such a revolutionary tool that GIS changed the way of reading and interpreting the landscape, integrate public and scientific information, and conduct research (Treitz, 2004; Battad et al., 2012).

GIS provided digital information about the studied area, identified by its geographical location. It was used to process data about objects defined by geographic location and a set of associated attributes, respectively the data acquired during the forest inventory stage (Petrea et al., 2014).

In protected forests which are almost unexplored, the data obtained by processing the satellite images from different periods could provide valuable insight into the development and stability of these forest ecosystems as well as for differentiation of vegetation units (Curovic et al., 2015).

Because the purpose of this research was to have a longterm management plan and to integrate wider range of data, all information can be correlated with each other or with other future data and statistics (Panda et al., 2010). Future focus and development will be mainly on system maintenance, including system enhancement and upgrading rather than to create a new system.

The following figures and graphs incorporate the data obtained and collected from the forest during the inventory stage, the topographic measurements for the precise spatial location, all incorporated into a GIS application to further enhance scientific assessment of biodiversity, forest data management and decision making at a local and national level. Thus, Carpinus betulus (hornbeam), 42.9\% (Fig. 4); Fagus sylvatica (beech), 24.9\% (Fig. 5); Quercus petraea (sessile oak), 23.2\% (Fig. 6); the number of other specimen of trees, $9 \%$ (Fig. 7), the total number of trees (Fig. 8), base diameter (Fig. 9), diameter at $1.30 \mathrm{~m}$ from base - 'dbh' (diameter at breast height) (Fig. 10), tree height (Fig. 11), crown diameter (Fig. 12), quality class (Fig. 13), self-pruning (Fig. 14) and insertion angle (Fig. 15) figures and graphs offer a superior representation compared with other methods, tables or software applications.

The numerous advantages of a GIS forestry application over the conventional inventory and older land records were confirmed. Besides the integrated database in geographic

Table 1. The arithmetic mean of the collected data from 411 specimens of tree species, grouped in 14 sample plots with each centre of known coordinates and elevation

\begin{tabular}{|c|c|c|c|c|c|c|c|c|c|c|c|c|c|c|c|}
\hline \multirow[b]{2}{*}{$\begin{array}{l}\text { Sample } \\
\text { plot }\end{array}$} & \multicolumn{3}{|c|}{ Coordinates and elevation } & \multirow[b]{2}{*}{$\begin{array}{l}\mathrm{Nr} . \\
\text { Beech }\end{array}$} & \multirow[b]{2}{*}{$\begin{array}{c}\mathrm{Nr} . \\
\text { Hornbeam }\end{array}$} & \multirow[b]{2}{*}{$\begin{array}{c}\mathrm{Nr} . \\
\text { Sessile }\end{array}$} & \multirow[b]{2}{*}{$\begin{array}{l}\text { Nr. } \\
\text { Others }\end{array}$} & \multirow[b]{2}{*}{$\begin{array}{l}\text { Nr. } \\
\text { Total }\end{array}$} & \multicolumn{7}{|c|}{ The main traits of the trees, as average values per sample plots } \\
\hline & $\mathrm{X}(\mathrm{m})$ & $Y(\mathrm{~m})$ & $\mathrm{Z}(\mathrm{m})$ & & & & & & $\begin{array}{l}\text { Diameter } \\
1.3 \mathrm{~m} \text { from } \\
\text { base }(\mathrm{cm})\end{array}$ & $\begin{array}{c}\text { Base } \\
\text { diameter } \\
(\mathrm{cm})\end{array}$ & $\begin{array}{l}\text { Height } \\
(\mathrm{m})\end{array}$ & $\begin{array}{c}\text { Crown } \\
\text { diameter } \\
\text { (m) }\end{array}$ & $\begin{array}{c}\text { Quality } \\
\text { class } \\
\text { (coef.) }\end{array}$ & $\begin{array}{c}\text { Self- } \\
\text { pruning } \\
(\%)\end{array}$ & $\begin{array}{r}\text { Insertion } \\
\text { angle }\left(^{\circ}\right)\end{array}$ \\
\hline 1 & 582233.354 & 388257.885 & 450.376 & 3 & 12 & 0 & 2 & 17 & 28.3 & 53.4 & 20.2 & 5.1 & 3.6 & 51.6 & 59.1 \\
\hline 2 & 582184.669 & 388431.582 & 498.467 & 35 & 0 & 0 & 0 & 35 & 25.9 & 35.7 & 22.5 & 4.8 & 1.8 & 56.1 & 47.3 \\
\hline 3 & 581995.588 & 388609.593 & 536.110 & 7 & 0 & 16 & 4 & 27 & 24.1 & 39.0 & 22.3 & 4.4 & 2.4 & 63.3 & 28.7 \\
\hline 4 & 581970.586 & 388659.051 & 537.072 & 2 & 12 & 8 & 7 & 29 & 26.4 & 43.9 & 24.2 & 6.7 & 2.1 & 67.4 & 31.2 \\
\hline 5 & 581911.899 & 388772.947 & 535.205 & 1 & 24 & 4 & 6 & 35 & 24.7 & 41.0 & 22.3 & 6.6 & 3.6 & 59.1 & 30.3 \\
\hline 6 & 581629.613 & 388781.533 & 539.565 & 26 & 1 & 7 & 0 & 34 & 26.6 & 44.2 & 26.4 & 6.2 & 1.6 & 75.0 & 35.4 \\
\hline 7 & 581393.914 & 388935.991 & 545.426 & 18 & 7 & 1 & 5 & 31 & 26.0 & 43.5 & 27.5 & 7.0 & 1.7 & 75.6 & 24.2 \\
\hline 8 & 581176.727 & 389108.491 & 551.189 & 6 & 12 & 21 & 1 & 40 & 26.1 & 39.9 & 27.6 & 7.6 & 2.3 & 68.3 & 31.5 \\
\hline 9 & 580981.642 & 389231.043 & 570.195 & 0 & 27 & 12 & 1 & 40 & 21.4 & 37.7 & 22.7 & 4.2 & 3.0 & 51.3 & 48.1 \\
\hline 10 & 580629.262 & 389233.577 & 598.511 & 0 & 8 & 10 & 3 & 21 & 25.3 & 45.8 & 21.7 & 4.4 & 2.9 & 51.7 & 47.4 \\
\hline 11 & 580475.384 & 389152.658 & 612.630 & 0 & 20 & 6 & 3 & 29 & 25.0 & 43.0 & 20.3 & 3.8 & 2.7 & 38.6 & 40.7 \\
\hline 12 & 580196.086 & 389241.535 & 633.903 & 1 & 13 & 7 & 2 & 23 & 29.3 & 53.4 & 25.1 & 4.3 & 2.8 & 41.7 & 42.0 \\
\hline 13 & 579789.686 & 389098.654 & 649.471 & 0 & 22 & 3 & 2 & 27 & 22.4 & 42.4 & 25.9 & 2.9 & 2.7 & 47.6 & 41.1 \\
\hline 14 & 579453.406 & 389003.038 & 666.194 & 5 & 18 & 0 & 0 & 23 & 30.9 & 48.8 & 28.2 & 4.7 & 2.5 & 42.8 & 41.1 \\
\hline
\end{tabular}


296

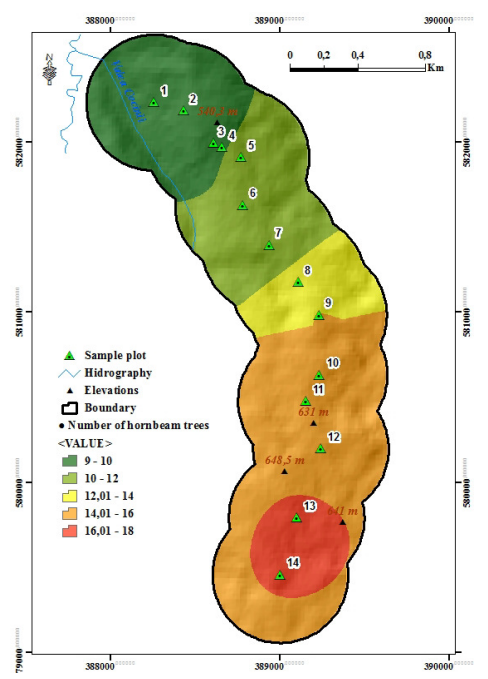

Fig. 4. Map illustrating the number of hornbeam trees per sample plot

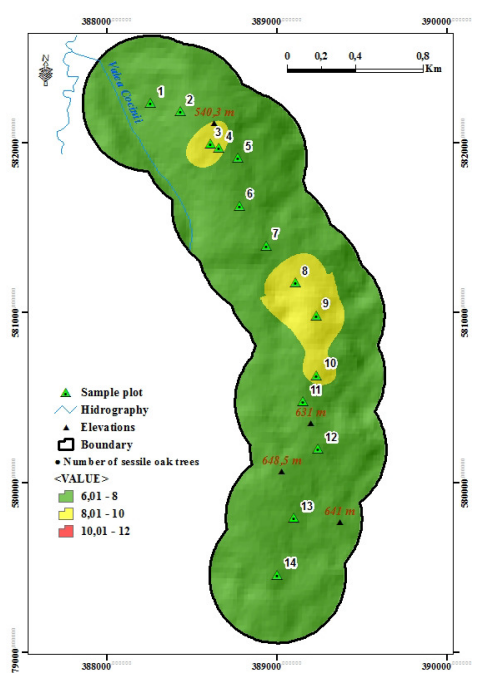

Fig. 6. Map illustrating the number of sessile oak trees per sample plot

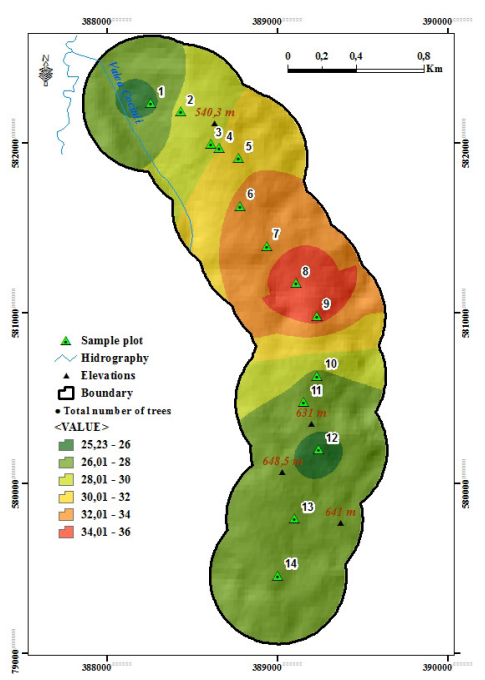

Fig. 8. Map illustrating the total number of trees per sample plot

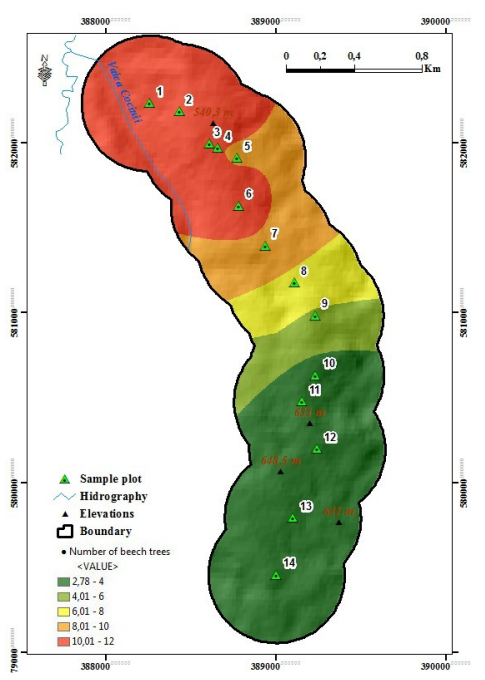

Fig. 5. Map illustrating the number of beech trees per sample plot

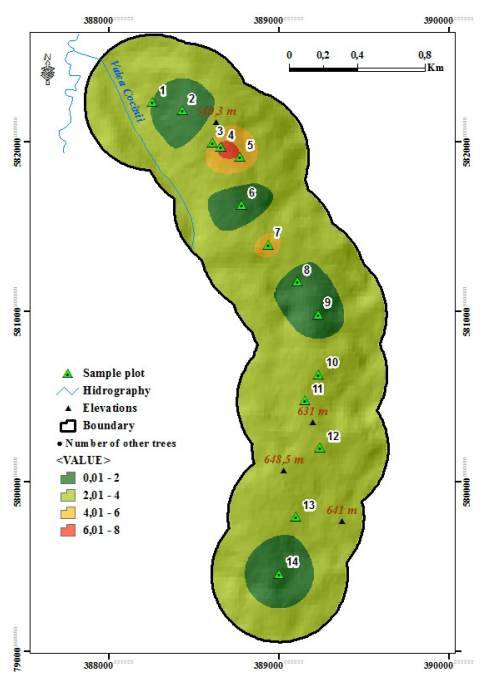

Fig. 7. Map illustrating the number of other trees per sample plot

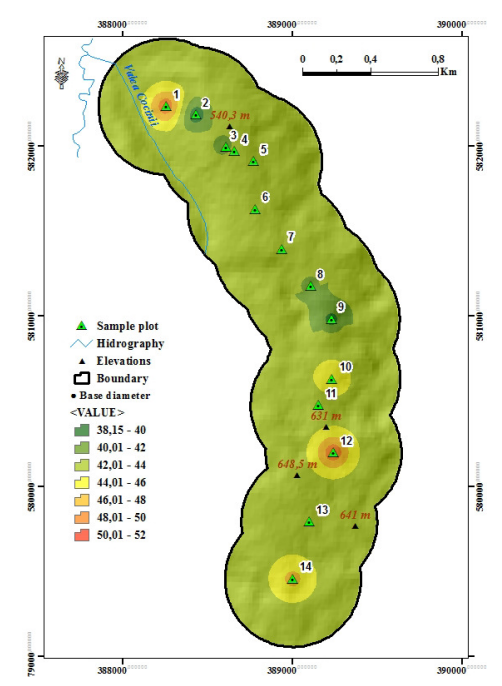

Fig. 9. Map illustrating the average trees base diameter per sample plot 


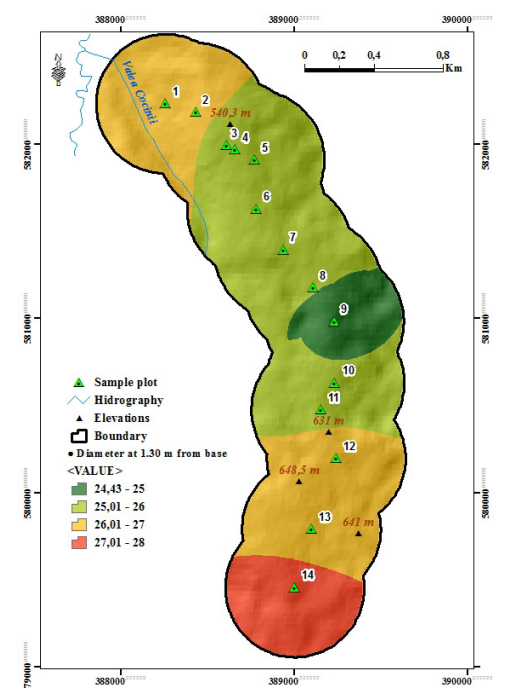

Fig. 10. Map illustrating the average trees diameter at $1.30 \mathrm{~m}-$ 'dbh' from base (diameter at breast height) per sample plot

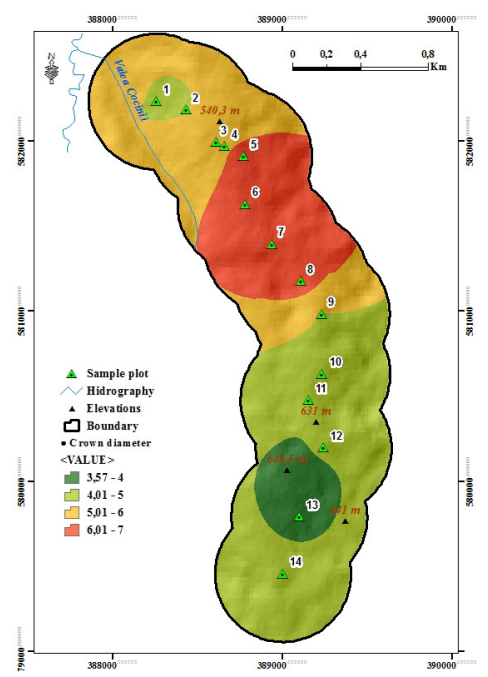

Fig. 12. Map illustrating the average trees crown diameter per sample plot

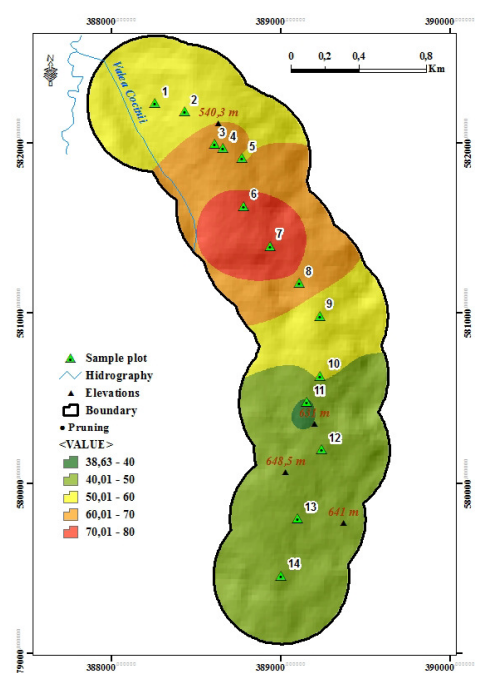

Fig. 14. Map illustrating the average trees self-pruning percentage per sample plot

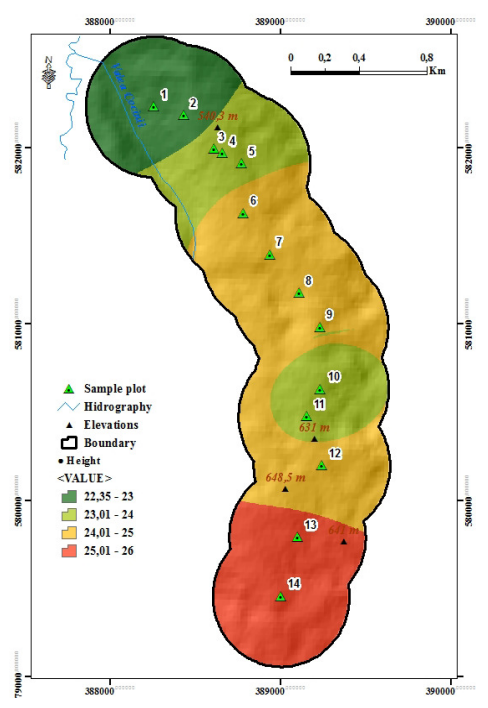

297

Fig. 11. Map illustrating the average trees height per sample plot

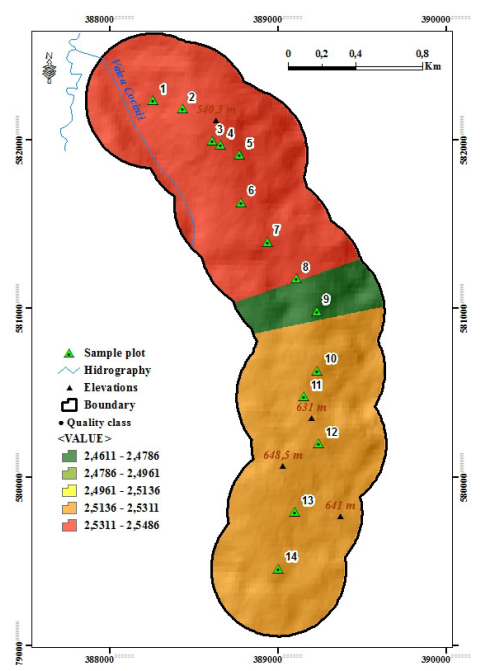

Fig. 13. Map illustrating the average trees quality class per sample plot

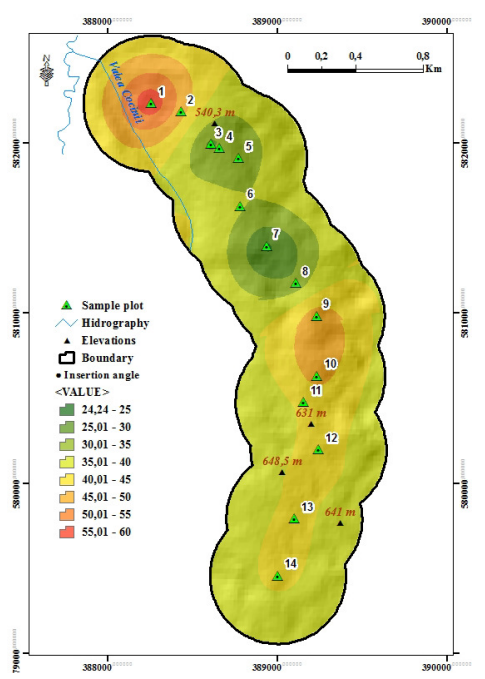

Fig. 15. Map illustrating the average trees insertion angle per sample plot 
298

location, such application can also help us extrapolate the data collected over larger areas. The method exploits the ability of GIS database to estimate forest inventory data on larger spatial coverage and nearby locations where no forest inventory was performed. This is of considerable importance since the results are relatively reliable and easily obtained. Moreover, improved, spatially explicit information of forest districts and trees specimens and characteristic is critical to management, decision making and improving ecosystem resiliency (García et al., 2003).

The extrapolation method with the best results was the Kriging extrapolation, and as a validation method for the obtained results, a second backtracking of forest inventory was made. The chosen measurements and forest inventory locations were between previous sample plots, predetermined locations chosen at the processing stage (Fig. 16), with the hopes of obtaining similar tree data from the field measurements and forest inventory to the Kriging extrapolation obtained in the GIS application. The chosen coordinates where exported from the geographic information system and staked out in the forest using the same GNSS RTK topographic instrument.

During the research it was used the principles of bivariate statistical analysis in order to determine the

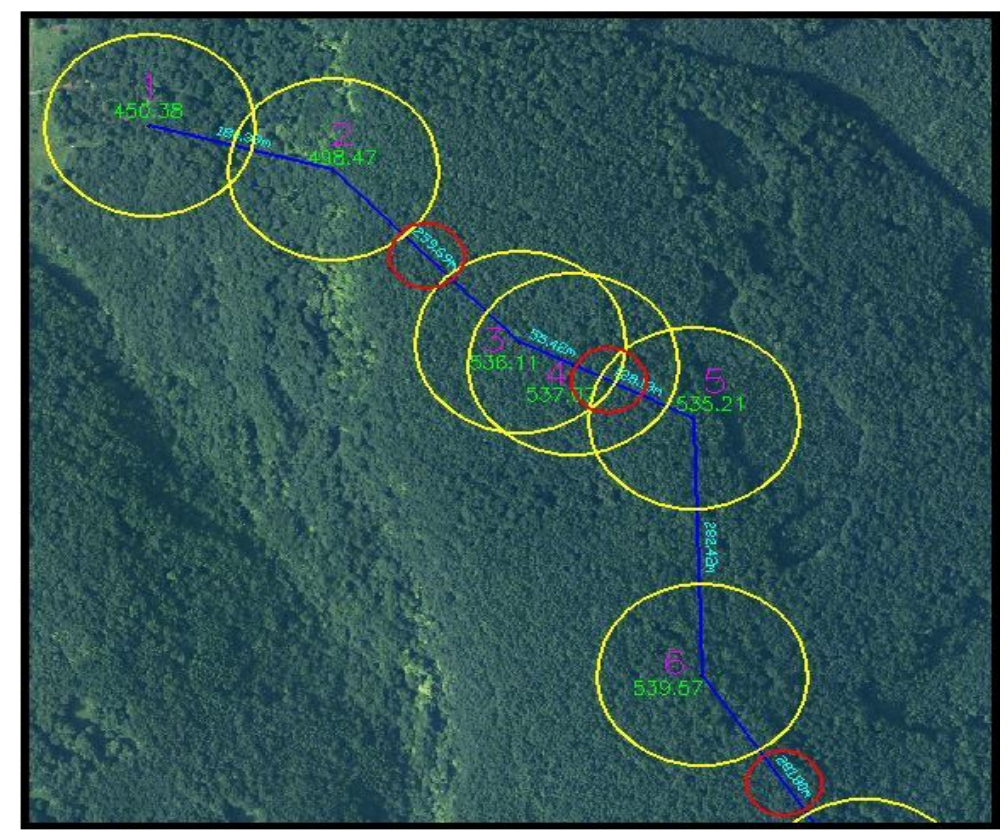

Fig. 16. Sketch illustrating a portion of the forest transect path; the yellow circles represent previous sample plots and the red circles are the chosen locations to verify the extrapolated data

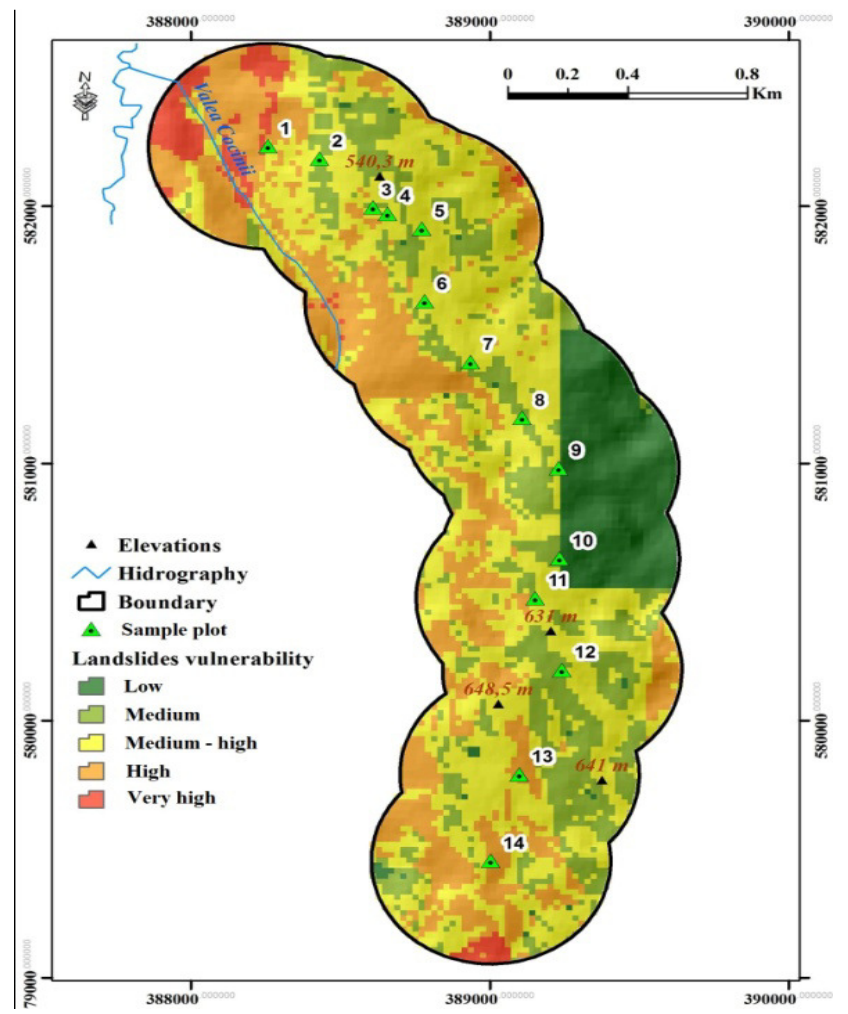

Fig. 17. Map for the probability of occurrence of landslides (classification) using the BSA model 


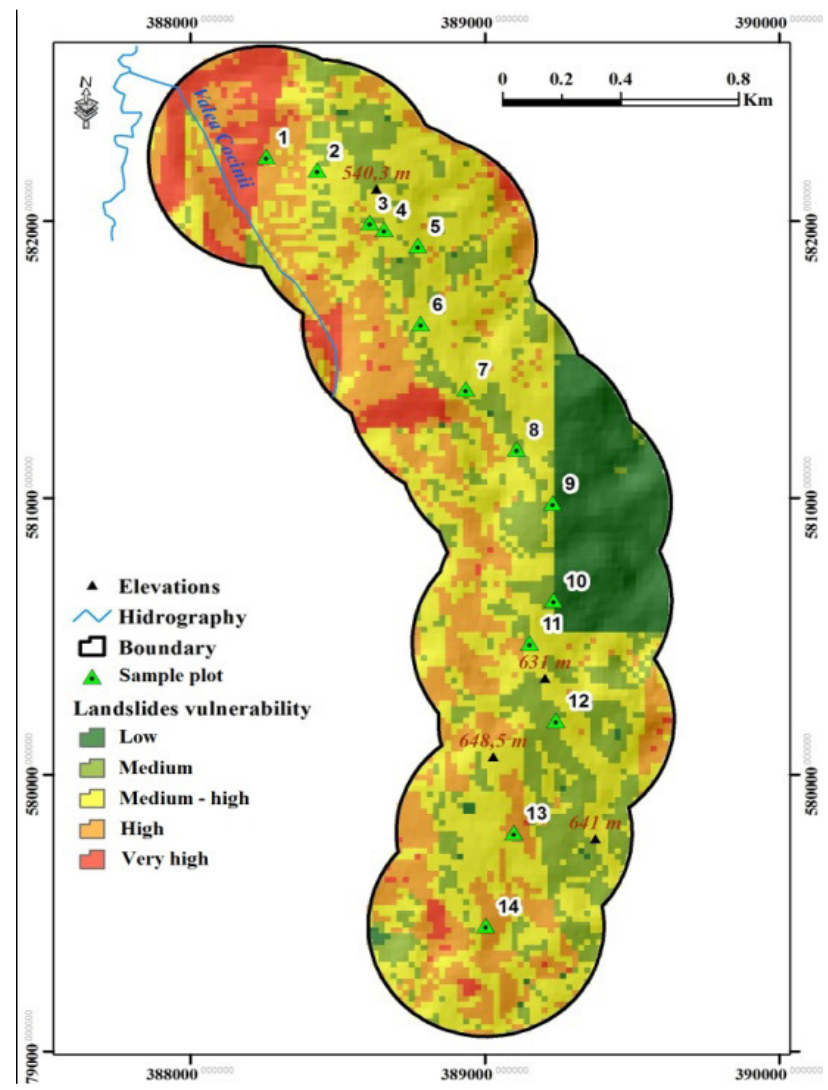

Fig. 18. Landslide susceptibility map without the land use data layer (forests)

dynamic potential of a territory, taking into account the statistical relationship between the independent variables represented by causal and trigger factors of landslides (slope, geology, land use etc.) in order to obtain a landslide susceptibility map of the studied area (Zêzere et al., 2003). The bivariate statistical analysis - BSA (Fig. 17) incorporates coefficients recommended in the specific methodology for determining the probability of landslides occurrence.

In order to identify the spatial susceptibility of landslides, a complex database is required that includes both triggering factors and causes of landslides (Coe et al., 2004). Among the numerous coefficients included in the spatial analysis and different layers, land use (in this case forests) represents one of the very important ones (Bilaşco et al., 2009). To further illustrate and highlight the importance of forests in such hilly terrains with geomorphology susceptible to hazards and landslides, a second landslide susceptibility map was created with the deliberate exclusion of the land use data layer (forests) from the spatial analysis model (Fig. 18).

The difference between the two created landslide susceptibility maps can be easily observed. In the event of a deforestation, the landslide vulnerability is greatly increased, especially in the North and West part of the studied area.

Regarding the correlations between the analysed characteristics, it can be concluded that between the tree height and the base diameter of the trunk there was a significant positive connection. It was noted that the diameter of the crown significantly influenced the diameter and height of the trunk.
Because Făget-Chinteni area is in the close vicinity to Cluj-Napoca city, the forest and species found inside can assure productive (as wood), ameliorative, ecological, landscape, cultural, educational, relaxation roles, and consequently has inestimable values. Even more, the forests surrounding the city offer an important role in the stability of the terrain the mitigation of landslides.

Interpretation of the results provided useful information on biodiversity in the area under consideration, as well as a good understanding of the concrete situations in each area. Based on the data obtained, the necessary measures can be taken to ensure the conditions and perpetuation of the plant species and associations of general interest as well as the co-existence of the anthropic factor and the forest, so that the forest resources in the Cluj-Napoca area are not exposed to risks, unavoidable alteration or even loss.

\section{Conclusions}

The evaluation of the forest ecosystems in the ClujNapoca area and the Forest District Cluj, as well as their characterization through biodiversity indices, aimed at obtaining some useful information to ensure the conditions necessary for the conservation of the diversity of plant species represented by the most important forest species in the area. Besides a superior representation using a GIS application implemented in forestry, further extrapolations are possible in order to accurately predict tree data inbetween or close to forest inventory sites. This process is very useful in administration, management and future 
300

decision makings by the local authorities and the National Forestry Directorate. By incorporating specific geomorphologic and land factors in the created GIS application, a very useful landslide susceptibility map can be created to help identify the areas with the most risks to natural hazards and further use of this data to mitigate this dangerous calamity.

\section{Acknowledgements}

The first author (PS) is thankful to the Doctoral School from UASVM Bucharest for the support received in his research during doctoral stage.

\section{References}

Aerts R, Honnay O (2011). Forest restoration, biodiversity and ecosystem functioning. BMCEcology 11(1):29.

Armaș I (2011). An analytic multicriteria hierarchical approach to assess landslide vulnerability. Case study: Cornu Village/Romania. Zeitschrift fur Geomorphologie 55(2):209-229.

Arnds, D, Böhner J, Bechtel B (2015). Spatio-temporal variance and meteorological drivers of the urban heat island in a European city. Theoretical and Applied Climatology 128(1-2):43-61.

Battad DT, Mackenzie P (2012). Applications of mobile GIS in Forestry South Australia. International Archives of the Photogrammetry, RemoteSensing and Spatial Information Sciences 39:447-452.

Bilaşco Ş, Horvath C, Cocean P, Sorocovschi V, Oncu M (2009). Implementation of the usle model using GIS techniques. Case study the Somesean Plateau. Carpathian Journal of Earth and Environmental Sciences 4:123-132.

Carrara A, Guzzetti F, Cardinali M, Reichenbach P (1999). Use of GIS technology in the prediction and monitoring of landslide hazard. Natural Hazards 20(2):117-135.

Coe JA, Michael JA, Crovelli RA, Savage WZ (2004). Probabilistic assessment of precipitation triggered landslides using historical records of landslide occurrence. Environmental and Engineering Geoscience 10(2):103-122.

Curovic M, Medarevic M, Spalevic V, Borgogno E, Motta R(2015). Forest type classification in the National Park of Biogradska Gora by integrating satellite images, digital geographical data and field measurements. Proceeding of the $5^{\text {th }}$ International Conference on Environmental and Material Flow Management, 05-07 November 2015,Zenica, Bosnia and Herzegovina pp 116-123.

Davis AJ, Thill JC, Meentemeyer RK (2017). Multi-temporal trajectories of landscape change explain forest biodiversity in urbanizing ecosystems. Landscape Ecology 32(9):1789-1803.

Dierwechter Y, Carlson T (2008). Effects of urban growth boundaries on residential development in Pierce County, Washington. The Professional Geographer 59(2):209-220.

Fikfak A, Kosanovc S, Konjar M, Grom JP, Zbašnik-Senegačnik M (2017). The impact of morphological features on summer temperature variations on the example of two residential neighborhoods in Ljubljana, Slovenia. Sustainability 9(1):1-20.

Fikfak A, Kosanovic S, Popovic SG (2015). Settlement patterns in an agrarian landscape - principles of classification in Goriška brda, Slovenia. Agriculture \& Forestry 61(4):319-335.
García M, Saatchi S, Casas A, Koltunov A (2003). Extrapolating forest canopy fuel properties in the California Rim Fire by combining airborne LiDAR and Landsat OLIData. RemoteSensing9(4):394412.

Hupy JP, Aldrich SP, Schaetzl RJ, Varnakovida P, Arima EY, Bookout JR, Wiangwang N, Campos AL, McKnight KP (2008). Mapping soils, vegetation, and landforms: an integrative physical geography field experience. The Professional Geographer 57(3):438-451.

Lwin KK, Murayama Y, Mizutani C (2012). Quantitative versus Qualitative Geospatial Data in Spatial Modelling and Decision Making. Journal of Geographic Information System (4):237-241.

Magiulo P, DiLisio A, Russo F, Zelano A (2008). Geomorphology and landslide susceptibility assessment using G.IS. and bivariate statistics: a case study in southern Italy. Natural Hazards 47:411-435.

Merem EC, Twumasi YA (2008). Using geospatial information technology in natural resources management: the case of urban land management in West Africa. Sensors 8:607-619.

Panda SS, Hoogenboom G, Paz JO (2010). Remote sensing and geospatial technological applications for site-specific management of fruit and nut crops: a review. RemoteSensing(2):1973-1997.

Petrea D, Bilașco Ș, RoșcaS, Vescan I, Fodorean I (2014). The determination of the landslide occurrence probability by GIS spatial analysis of the land morphometric characteristics (case study: the Transylvanian Plateau). Carpathian Journal of Earth and Environmental Sciences 9(2):91-102.

Peyret F, Betaille D, Hintzy G (2000). High-precision application of GPS in the field of real-time equipment positioning. Automation in Construction 9:299-314.

Pirti A, Gümüş K, Erkaya H, Gürsel Hoşbaş R (2010). Evaluating repeatability of RTK GPS/GLONASS near/under forest environment. Croatian Journal of Forest Engineering: Journal for Theory and Application of Forestry Engineering 31(1):23-33.

Pirti A, Yucel MA, Gumus K (2013). Testing Real Time Kinematic GNSS (GPS and GPS/GLONASS) methods in obstructed and unobstructed sites. GeodetskiVestnik 57(3):498-512.

Poesen J, Nachtergaele J, Verstraeten G, Valentin C (2003). Gully erosion and environmental change: importance and research needs. Catena 50(2):91-133.

Rickli C, GrafF (2009). Effects of forests on shallow landslides - case studies in Switzerland. Forest Snow and Landscape Research 82(1):33-44.

Roşca S, BilaşcoŞ, Petrea D, Fodorean I, Vescan I, FilipS (2015). Application of landslide hazard scenarios at annual scale in the Niraj River basin (Transylvania Depression, Romania). Natural Hazards 77(3):15731592.

Stewart DJ (2010). New tricks with old maps: urban landscape change, GIS, and historic preservation in the Less Developed World. The Professional Geographer 53(3):361-373.

Tasoulas E, Varras G, Tsirogiannis I, Myriounis C (2013). Development ofa GIS Application for Urban Forestry Management Planning. Procedia Technology 8:70-80.

Treitz P (2004). Remote sensing for mapping and monitoring land-cover and land-use change. Progress in Planning 61:269-279.

Zêzere JL, Rodrigues ML, Reis E, Garcia R, Oliveira S, Vieira G, Ferreira AB (2003). Spatial and temporal data management for the probabilistic landslide hazard assessment considering landslide typology. Landslides: Evaluation and Stabilization 1:117-123. 